\title{
A Study of Postmodern Narrative in
}

\section{Michael Cunningham's The Hours}

\author{
Hajar Abbasi Narinabad \\ Address: 43, Jafari Nasab Alley, Hafte-Tir, Karaj, Iran \\ Tel: 00989370931548 E-mail: hastiabbasi63@yahoo.com
}

Received: 30-06- 2012

Accepted: 30-08- 2012

Published: 01-09- 2012

doi:10.7575/ijalel.v.1n.4p.257

URL: http://dx.doi.org/10.7575/ijalel.v.1n.4p.257

\begin{abstract}
This project aims at providing a detailed analysis of the major features of the theory of postmodern narrative and at going through the novel The Hours by the American writer Michael Cunningham concentrating on some postmodern narrative techniques. To do so, the researcher goes through the theories set forth by some postmodern theoreticians like Roland Barthes, Jacque Derrida, Jean-François Lyotard and Julia Kristeva to investigate the postmodern narrative techniques and elements used in the novel. The researcher first examines the theories and then critically applies them on the novel. The article goes through the most eminent elements of postmodern narrative including intertextuality, stream of consciousness style, fragmentation and representation respectively which are delicately utilized in The Hours. The article concludes by recommending a few directions for the further research.
\end{abstract}

Keywords: Intertextuality, Stream of Consciousness, Fragmentation, Postmodern Reality

\section{Introduction}

Narratologists have tried to define narrative in one way or another; one will define it without difficulty as "the representation of an event or sequence of events"(Genette, 1980, p. 127). In Genette's terminology it refers to the producing narrative action and by extension, the whole of the real or fictional situation in which that action takes place (Ibid. 27). But some narratologists such as Onega and Londa believe that "what we get in a narrative text are not events as such, but signs (1996, p. 5). Or as it is defined by Mieke Bal "A story is a fabula that is presented in a certain manner. A fabula is a series of logically and chronologically related events"(1985, p. 5). Whatever the deficiencies of narratology may be, its influence has been considerable; however, none of the efforts to define narratology may be thorough, especially regarding postmodern narrative.

As it is stated in Encyclopedia of Postmodernism, since its inception as a literary term in the late 1950s and its wider use as a critical term in the 1980s and 1990s, postmodernism has emerged as a significant cultural, political, and intellectual force that defines our era. Postmodernism has consistently challenged our understanding of unity, subjectivity, epistemology, aesthetics, ethics, history and politics (2003, p. xiii). Definitions of postmodernism range from "eclecticism" (practice of taking and combining elements from many different systems) and "montage" (juxtaposition of separate parts to create a whole), to "neoscepticism" (resisting to anything that was believed to be true) and "anti-rationalism". Consequently its characteristics are not limited to several factors and cover a wide range of factors (Ibid). Postmodern fiction has made use of various techniques employed in the narrative tradition inventing a new terminology to deconstruct the whole narrative tradition. Moreland states that reality is a social construct, contextual to cultural conditions and characteristics, and defined by communities or societies based on their language - their common narrative (2005, p. 146). Since postmodern narrative enjoys a wide range of elements, the researcher is not supposed to cover its all elements. . Of the existing factors in postmodern narrative the researcher is going to work on, intertextuality, stream of consciousness style, fragmentation and representation respectively, which are used in Michael Cunningham's novel The Hours. To illustrate such arguments the researcher will mostly examine outstanding theoreticians such as Roland Barthes, Jean-François Lyotard, Jacque Derrida, Julia Kristeva. Regarding the above mentioned points about postmodern narrative, the researcher is going to elaborate on the four perceivable characteristics of it. 


\section{Aim of the Study}

The purpose of the present thesis is to delve into the postmodern theories involved in narrative techniques, and to describe and analyze the manifestation of this theory in the American novel The Hours. The questions the researcher hopes to answer in this project are as follows:

1. Which postmodern narrative elements and modes of combination are used to narrate The Hours?

2. How is reality represented through postmodern elements in The Hours?

3. How does The Hours come to unification in spite of all fractured and individual stories existing in it?

4. How is the postmodern narrative within narrative technique used in The Hours?

\section{Intertextuality in Postmodernism}

The postmodern term "intertextuality," which focuses on the interplay and interrelation of texts, was first defined by Julia Kristeva in the late 1960s. It has been advanced by Julia Kristeva since its first introduction in her essay of 1969, translated as "Word, Dialogue and Novel". She developed her own idea of intertextuality from reading the work of Mikhail Bakhtin, the Russian formalist.

In "An Interview with Julia Kristeva," Kristeva herself says that the conception of intertextuality is important in the postmodern age: "In postmodernism, the question of intertextuality is perhaps even more important in certain ways, because it assumes interplay of contents and not of forms alone" (1984, p. 282). Kristeva demonstrates the key point of intertextuality: "it is a postmodern concept that involves interplay of contents." Since intertextuality is a postmodern term, it is impossible to "speak of originality or the uniqueness of the artistic object, be it a painting or a novel" (Allen, 2000, p. 5).Thus, intertextuality treats literary works as texts relating to other texts; a text is never original and independent of other texts. A text always relates to another text; it is never alone. Kristeva examines and interprets Bakhtin's "dialogism" as intertextuality. According to Kristeva "Bakhtin situates the text within history and society, which are then seen as texts read by the writer, and into which he inserts himself by rewriting them" (1984, p. 36) thus meaning that a writer is affected by his/her society, history, culture either consciously or unconsciously and brings that to the text by rewriting them. She is affected by Bakhtin's theory and revises Bakhtin's idea of dialogism in order to develop her own concept of intertextuality. Kristeva expands dialogism, which concerns about utterances and voices, and believes that it considers "the results of the intersection of a number of voices" (1984, p. 281). To Kristeva, dialogism deals not only with sounds and voices but also with the narrative sentences and discourses in a text. Therefore, dialogism does not merely refer to the direct and literal dialogues. It emphasizes various intersections and results when different discourses collide with each other. For Kristeva, the story is a proper form of intertextuality. Kristeva and Barthes believe that text is like "a tissue, a woven fabric" (Allen, 2000, p. 5).

Michael Cunningham' novel can be studies as an intertextual text of Virginia Woolf's book, Mrs. Dalloway. As in his article "Cunningham Finds God in the Details" Harrison has put it, Cunningham believed Mrs. Dalloway is "always in the back of my mind even as I read hundreds of other books" (2002). In other words, Cunningham is strongly impressed by Woolf's work. Furthermore, Cunningham himself calls The Hours "a riff on British novelist" (Online News Hour, 2002). That is to say, the interrelation of Mrs. Dalloway and The Hours can be expected and discovered as Tory Young puts it in her Reader's Guide to The Hours: "The relationship between The Hours and Mrs. Dalloway is impossible to simplify; Cunningham interweaves aspects of Woolf's life, her novel, and her theories" (2003, p. 38).

\subsection{Traces of Intertextuality in The Hours}

The characters in The Hours are so much like those in Mrs. Dalloway; however, just some important parts of them are going to be mentioned in the following part:

\subsection{1 "Mrs. Dalloway" in The Hours and Clarissa Vaughan in Mrs. Dalloway}

In both stories, The Hours and Mrs. Dalloway, Clarrisa Dalloway and Clarissa Vaughan are giving party in the evening and so are doing some preparations for it. Woolf's Clarrisa Dalloway is receiving some guests of her in London and Clarrisa Vaughan is having a party for her friend Richard who has just won the Carrouthers Prize because of his outstanding literary abilities: "Tonight she will give her party. She will fill the rooms of her apartment with food and flowers, with people of wit and influence. She will shepherd Richard through it, see that he does not overtire, and then she will escort him uptown to receive his prize" (The Hours, p. 13).

The noteworthy point here is that Clarrisa Vaughn is named Dalloway by Richard. When Richard saw her he 
International Journal of Applied Linguistics \& English Literature

ISSN 2200-3592 (Print), ISSN 2200-3452 (Online)

Vol. 1 No. 4; September 2012

said: "why, hello, "Mrs. Dalloway" ..... she should, he said, be named after a great figure in literature" (Ibid.10).

Cunningham also deals with feeling of loneliness and insignificance in the part dealing with "Mrs. Dalloway". When Clarissa Vaughan knows that she is not invited to the luncheon party, she thinks, "I am trivial, endlessly trivial" (p. 94). She believes that she is an old and trivial woman who is only supposed to give parties and her absence from the world does not make any difference to others. Similarly,Woolf'sMrs.Dalloway feels isolated and depressed when she comes to know that Lady Bruton has not invited her to lunch (Mrs. Dalloway, pp. 34-35). Both Clarissas have the sense of loneliness. As for the party in Mrs. Dalloway, Clarissa thinks that she is only "someone who thinks too much about parties" (p. 161) and only cares about trifles of life.

Another point worth mentioning is that neither mother in these novels has a close relationship with their only daughters. Both of their daughters get along well with their poor tutors leading their mothers feel jealous and bad about the tutors. Secondary characters also play roles identical to their counterparts in Woolf. In Mrs. Dalloway, Clarrisa is annoyed as her charming daughter Elizabeth is "closeted" in her room with poor and not good looking Miss Kilman who has a great passion for Christianity (p. 130). Correspondingly, in The Hours, Clarrisa while walking in the street talks to her daughter in her mind and thinks "You want to like Mary Kurl, you struggle to, but she is finally too despotic in her intellectual and moral intensity... she mocks you, privately, for your comforts and your quaint (pp. 23-24).

\subsubsection{Richard in The Hours and Septimus Warren Smith in Mrs. Dalloway}

Both Richard in The Hours and Septimus in Mrs. Dalloway are suffering from mental illnesses. In The Hours, Richard is suffering from AIDS and his home is described by many negative adjectives such as "squalid," "nubby," "no-colored," "darkened," "damp," and "irreversible rot" (pp. 52-59) all signifying the nearby death that surrounds him. Eventually he gives up and commits suicide by jumping down the window:

Mrs. Dalloway rushes in to the other room and finds Richard still in his robe, parched on the still of the open window, straddling it, with one emaciated leg still in the apartment and the other invisible to her... Richard smiles. He says," I don't think two people could have been happier than we've been." He inches forward, slides gently off the sill, and falls. (pp.198-200)

The same happenings take place to Mrs. Dalloway's Septimus, a soldier suffering shell shock after the First World War who seems to be insane and in the end throws himself out of a window and plunges into death while his doctor is trying to push himself by force to his room and his wife is trying to avoid him come in (p. 184).

\subsubsection{The Hours' Mrs. Woolf}

in the part dealing with Mrs. Woolf's story, as Virginia is trying to write the story she has started after she goes back upstairs, she decides to write for an hour and then have lunch and then picks up her pen and with no idea about where to begin or what to write suddenly she writes: "Mrs. Dalloway said she would buy the flowers herself" (italics in the original, 35) thus referring directly to Woolf's Mrs. Dalloway.

\section{Fragmentation in Postmodernism}

One feature of postmodernism that makes it different from modernism is the way postmodern authors look at fiction. While the modernist authors considered precision both in form, style and presentation a very significant point, the postmodernist breaks with these established tradition. A considerable aspect of postmodernism in literature is breaking with strict time lines, called discontinuous time. As Barthes puts it, there are "tales within tales within tales" in which the author constructs a sequence of events that have no time relationships to each other. To postmodern thought, any attempt to make use of grand narrative is criticized and questioned. It agrees with Lyotard's call to claim that "we have paid a high enough price for the nostalgia of the whole and the one, for the reconciliation of the concept and the sensible, of the transparent and the communicable experience." Then, he suggests "a war on totality" in order to "activate the differences and save the honor of the name" (1984, p. 81). The notion of fragmentation is observed in the nonlinear and deconstructed aspects of many postmodern novels. Hutcheon, claims that "Narrators in fiction become either disconcertingly multiple and hard to locate or resolutely provisional and limited - often undermining their own seeming omniscience" (1987, p. 17) questioning all totality, unity and wholeness. In postmodern texts, the authors deny the ultimate accepted values of a society about totality and wholeness. In his essay "Structure, Sign and Play in the Discourse of the Human Sciences", Derrida has mentioned his own notion of center in stories. According to him, a center is that part of a structure which focuses and organizes the entire system. Derrida declares searching for a center has become a part of West's life being obsessed with it all the time. According to him the center tries to unite the system and 
International Journal of Applied Linguistics \& English Literature

ISSN 2200-3592 (Print), ISSN 2200-3452 (Online)

Vol. 1 No. 4; September 2012

narrow down the amount of fragmentation in "the total form" (1966, p. 278). In postmodern narrative play is simply any shift in the structure, any unplanned, unordered event helping with "the rupture" of the notion of the structure: it decentered the structure. "The center is not the center," as Derrida says. This means that "the concept of centered structure ... is contradictorily coherent" (Ibid, p. 279).

Cunningham's The Hours is basically three different stories in one volume, divided and then aligned newly to convey the jumping between three different time periods and three different main characters, who are somewhat intertwined but separated throughout most of the story. Cunningham seems to have been able to balance or explore themes successfully, subtly linking the three characters through alternating chapters.

\subsection{Fragmentation in The Hours}

In each of these narratives, there are three women who want to make, as Mrs. Dalloway, "an offering". They do some physical objects to assert their right to existence and their contributions to the world. They struggle with "proportion," and these undertakings carry much more weight than perhaps they should. They live for the moments when their aspirations and reality meet: "She is herself and she is the perfect picture of herself; there is no difference." (The Hours, p. 76)

Although it seems that all these stories are about different women in diverse periods of history; eventually, the reader comes to know that all of them are related to one another through the story of Mrs. Dalloway.

Each of three parts in The Hours - "Mrs. Brown," "Mrs. Dalloway," and "Mrs. Woolf" is divided into several episodes and each part talks about one female character respectively: Laura Brown, Clarissa Vaughan and Virginia Woolf. The three women in The Hours are presented in one routine day in their lives. One narrative centers on a day of Virginia Woolf in 1923 when she starts writing Mrs. Dalloway, the other on Laura Brown's one day life in 1949 reading Mrs. Dalloway and the third one on Clarissa Vaughn, hosting a party in the late twentieth.

Cunningham carefully blends together different women's lives in different times and periods to show that all their lives are related to each other and they have all the same dilemmas. As Cunningham depicts, "it's three stories that take place at three different times - immediately after or during an event that has changed the world, and each involves a woman trying to find a way to live a world that is no longer what it was" (Lit Chat"DanceswithWoolf", 2000).

The last episode of "Mrs. Dalloway," also the ending of Cunningham's novel combines Mrs. Dalloway with Mrs. Brown. After Richard's death, Clarissa goes to find Laura. Her first words to Laura are "Here we are" (p. 217). It has two levels of meaning. The first one is that Clarissa tells Laura that they have arrived at her house. However, the second level is more significant: Clarissa and Laura are those who survive in the end. After Richard's death, Clarissa realizes her older age, but she knows that she will go on. When she sees Laura, she treats her as a strong woman who has faced the difficulties of life yet still successfully surviving. Besides, they are now in the same time and space that is the present. They do not live in the past anymore, as Richard always did. Van der Laan (2002) b e $1 \mathrm{i}$ e v e s Cunningham unites the two women in the present in order to express that "all human beings are interconnected in ways they may not fully understand". In other words, both Clarissa and Laura are linked by the death of Richard. They are destined to be united as one. They are both united as one and each "finds her way to some kind of transcendence, to some sort of happy ending, though it may not be the happy ending that she had in mind for herself" (Online News Hour "The Pulitzer for Fiction"). It may not be necessarily the ending that they want, but their life will continue. Cunningham's ending echoes with the love of life and expands to the people living in the present. Life is just like an endless circle, and "Heaven only knows why we love it so" (p. 226).

To sum up, The Hours has three detached and fragmented strands, which all go along with the story of Mrs. Dalloway and make distinct units associating with it in one way or another.

\section{Stream of Consciousness in Postmodern Narrative}

The term "stream of consciousness" was originally used as a psychological term. In literature, it indicates a writing approach for presenting the "psychological aspects of character in fiction" (Humphrey, 1965, pp. 1-2). In a postmodern narrative the inner mind of the characters is described and the reader comes to know the story or reality as it passes through the mind of the characters rather than explained by a narrator.

Ricoeur states that a stream-of-consciousness novel, spotlights "the incompleteness of personality, the diversity of the levels of the conscious, the subconscious, and the unconscious, the stirring of unformulated desires, the inchoative and evanescent character of feelings" (1985, p. 10). In other words, stream-of-consciousness 
novelists aim to discover and emphasize the irrational and disordered part of the individual consciousness, presenting the psychic life of each character. Henri Bergson, the French philosopher, manifests that people should go into the "original" part of consciousness. According to Kumar, Bergson asserts that novelists should "possess the original" so that they may "faithfully follow reality and adopt "the very movement of the inward life of things"(1963, pp. 19-20). That is to say, Bergson treats the inner consciousness as the original part of life. He repeatedly suggests that a novelist has to record the "internal rhythms of thought and experience" since they are more important than outer descriptions (Ibid, p. 21). Furthermore, Bergson claims that consciousness has its fluidity. In An Introduction to Metaphysics, he says:

There is no state of mind, however simple, which does not change every moment, since there is no consciousness without memory and no continuation of a state without the addition, to the present feeling, of the memory of past moments. (1949, p. 40)

Since consciousness includes individual feelings and memories, it is always fluctuating. Bergson emphasizes the "fluidity in our states of consciousness" (Richter, 1970, p. 7) and encourages a novelist to go down into the "inner flux" (ibid, the italic is in the original). As a result, Bergson pays attention to the inner flux of consciousness and thinks that a novelist should represent the characters' inner and flowing thoughts. Humphrey declares that the fluidity of consciousness can be described as a "stream." William James, who coins the term "stream of consciousness," discovers that consciousness, which includes memories, feelings, and thoughts, "appears to one, not as a chain, but as a stream, a flow" $(1965$, p. 5).

Similar to Bergson, James puts emphasis on the fluidity of inner consciousness. In his definition, James asserts that consciousness is a changing process: Such words as "chain" or "train" do not describe it [consciousness] fitly as it presents itself . . It is nothing joined; it flows. A "river" or a "stream" is the metaphors by which it is most naturally described (Kumar, 1963, p.14). Consciousness runs freely and endlessly like a stream. It is not controlled by human beings' reason and intellect. Moreover, consciousness is never static; it is dynamic. As a result, according to Humphrey consciousness, with its fluid trait, has the ability to "move freely in time- its tendency to find its own time sense" (1965, pp. 42-43). Consciousness is not constrained by time.

\subsection{Stream of Consciousness in The Hours}

Cunningham's The Hours can be treated as a stream-of-consciousness novel. Cunningham depicts some parts of the story to the reader through characters' inner minds and thoughts. In the beginning of the novel, he quotes Woolf's words in her diary in 1923:

I have no time to describe my plans. I should say a good deal about The Hours and my discovery: how I dig out beautiful caves behind my characters: I think that gives exactly what I want; humanity, humor, death. The idea is that the caves shall connect and each comes to daylight at the present moment. (1981, p. 59)

That is a proof to Cunningham's idea of using stream of consciousness style to save time, show their inner mind and story of their lives and connect their lives together.

In the part dealing with Mrs. Woolf' story, Virginia thinks about Clarissa Dalloway, while she is passing across the street, Virginia thinks that "Clarissa will have a love: a woman. Or a girl, rather; yes, a girl she knew during her own girlhood; one of those passions that flare up when one is young” (81) and thinks about Clarissa's love: Sally Seton, who "will scandalize the aunts by cutting the heads off dahlias and hollyhocks and floating them in great bowls of water, just as Virginia's sister, Vanessa, has always done” (82). In doing so, Cunningham records Virginia's inner thinking about Clarrisa as well as providing the reader with some information about Vanessa. Furthermore, Cunningham represents Woolf's idea of Clarissa by going in to her inner mind. When Virginia deals with servants in The Hours, she thinks about Clarissa. Since she is not a competent hostess, Virginia plans to let Clarissa have "great skill with servants, a manner that is intricately kind and commanding. Her servants will love her. They will do more than she asks (p. 87). Again, Cunningham describes Virginia's inner thinking while she is dealing with Nelly the maid. He also connects Virginia's outer life with her inner thought.

In The Hours, characters' experiences of actual events and their emotional reactions to them are as well brought up in their minds. When Clarissa enters Richard's apartment for the first time in the novel she thinks as if she is standing in another time:

The apartment has, more than anything, an underwater aspect. Clarissa walks through it as she would negotiate the hold of a sunken ship. It would not be entirely surprising if a small school of silver fish darted by in the half-light.... She feels as if she has passed through a dimensional warp - 
through the looking glass, as it were; as if the lobby, the stairwell, and hallway exist in another realm altogether; another time. (p. 56)

Moreover, Cunningham successfully shows Mary Krull's and Clarissa's feelings toward each other by moving between their consciousness. In the meeting of the two women, Cunningham depicts Mary's thoughts: Fool Mary thinks though she struggles to remain charitable or, at least, serene (160, italic in the original). Cunningham goes into Clarissa's consciousness as well: "What, exactly, was wrong with the ring? . . Fraud, Clarissa thinks. You've fooled my daughter, but you don't fool me. I know a conquistador when I see one. I know all about making a splash" (160, italic in the original). By moving between the consciousness of Mary and Clarissa, Cunningham creates a silently mental conversation. It is a dialogue without actual voices between them. The passage also expresses the hatred between Mary and Clarissa.

In the part dealing with Mrs. Woolf, when her husband Mr. Woolf asks her if she had lunch and she answers no he stands there before her and thinks:

She may be the most intelligent woman, he thinks. Her books may be ready for centuries. He believes this more ardently than does anyone else and she is his wife... She is still regal, still exquisitely formed, still possessed of her formidable lunar radiance, but she is suddenly no longer beautiful. (p. 33)

Using the technique of stream of consciousness, Cunningham also moves from one period or time to another and breaks temporal bondages of time. In the part dealing with "Mrs. Dalloway," after Clarissa pushes open the florist door and goes in, she stands in the dim and recalls her childhood:

There was that branch tapping the windowpane and there was another, though she'd been older, five or six, in her own bedroom, this branch covered with red leaves . . she remembers loving the autumn branch for reminding her of the earlier branch, tapping against the window of a house to which she would never return, which she could not otherwise remember in any of its particulars. Now she is here, in the flower shop. (pp. 24-25)

Remembering the past, Clarissa goes back to her childhood and recollects the branch tapping at a window. The existence of Clarissa flows in time back and forth. Thus, the linearity of time is broken.

Besides, in the part of "Mrs. Brown," after Laura reads some parts of Mrs. Dalloway she inhales deeply, remembers Dan and goes back to five years ago: "less than five years ago Dan was believed to have died at Anzio, and when he was revealed two days later to be alive after all... and when he came back to California he was received as something more than an ordinary hero... and proposed to his best friend's older sister... what could she say but yes"(pp. 39-40).

Consequently, Cunningham, by entering and recording characters' inner consciousness, breaks the limitation of the chronological time.

\section{Representation of Reality in Postmodern Narrative}

If there is the capability of talking about reality or truth at all, postmodern focuses on various modes of representing and coming to terms with it, not a specific medium. J.F. Lyotard suggests that all forms of representation rely upon narrative in order to validate themselves, and it could be said that all knowledge is primarily narrative as, no matter their medium, all artistic and cultural representations require some meta narrative to explain, validate or justify them ( 1984, p. 7$)$. This clarifies an obvious contrast between reality and how we perceive it and a constant awareness regarding the link between forms of representation and the developing reality can be traced. Postmodernism is often associated with narrative, and a corresponding relationship between story and postmodernism can be traced in much postmodern stories. As Crew mentions it is much more than that many instances of postmodernism occur in the novel form. It is more than a coincidence, and the basis of this relationship rests on the fact that both the novel and postmodernism can be considered as oppositional discourse, as both involve a relationship, or a variety of relationships of antagonism or opposition towards already existing forms of representation which are considered and consider themselves to be valid, authentic, authoritative, or even realistic $(1999$, p. 20). The history of the novel is all about not existing any one objective and united reality and that it is the reader who changes what he observes and experiences. Genette believes that narrative is not a "weakened, attenuated mode of literary representation" (1982, p. 130). The developing awareness of this state of affairs has been reflected in the development of the novel towards postmodernism. Postmodernism tries to oppose reality against literature making use of almost any mode of narrative assimilated into the novel. According to Michael Holquist and Walter Reed the story is "essentially tied to realism whenever realism is conceived as more real than literature since the novel always operates in reaction to literature" (1988, p. 417). Many novels or dramas arising after modernism have acted against previous modes of representation within literary culture attempting to be more realistic or trying other options to both

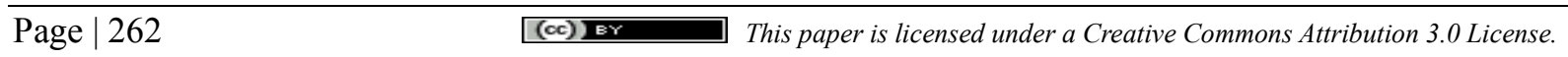


literary and non-literary forms to manifest reality in the current culture. To understand the corresponding relation between postmodernism and literature Shklovsky's theory about the history of narrative should be studied. He sees it as a continual making strange or defamiliarization, which has brought about the constant renewal of the form (Lemon \& Reis, 1965, p. 57). Bakhtin shares a similar view, but sees narrative as defamiliarizing different ways of talking about the world (1981, pp. 5-38). Reality and the form of representing it can be defamiliarized and manifested unfamiliar. According to Bakhtin, in postmodern literature the present is more focused because the concept of time has changed which opposes the traditional concept of unity or wholeness. It mostly focuses on contemporary history and a reality which is continually moving through present and present. He claims that novel has an original way of forming time and the absolute past tradition has no role in the creation of the novel as a genre. According to him the novel was created exactly when the object of representing reality was being disgraced to the level of a contemporary reality that was ambiguous and adaptable (1981, p. 38). In postmodernism the story returns to a sense of indecisiveness and defectiveness receding the present which is much more different from our contemporary awareness.

To sum up, rewriting history, dislocating time and voices, using intertextuality, deforming the real, using symbols, fragmenting stories, highlighting the absurdity of logic and system, defamiliarizing the intermediary role of narrative and exaggerating the immanence that projects and imposes human desires and structures on reality are some ways of representing reality in postmodern narrative.

\subsection{Representation in The Hours}

According to Hughes, The Hours moves away from Mrs Dalloway and is a re-telling of Mrs Dalloway; however, there are some variations made and Cunningham has added new elements to this novel. As Hughes puts it in her article on The Hours:

Although The Hours contains a similar cast of characters to those of Mrs. Dalloway and repeats the themes of love and death and time, Michael Cunningham does not simply ape the structure of Mrs. Dalloway and transpose it to New York in the late twentieth century. (2004, p.350)

One way of representing reality is using intertextuality, but at the same time defamiliarizing it in different ways. Cunningham creates a dialogue and subverts the traditional conception of Woolf. In a postmodern narrative we can defamiliarize what we ought to understand about the nature of our own world and our knowledge of it.

Defamiliarization can be done through characterization. Whereas The Hours' Woolf is named after a literary figure, she does not have the same characteristic of Virginia Woolf who seemed to be strange and complex and have special mental condition and behavior. Mrs. Woolf in The Hours lacks the complexity that is essential to Woolf's life and writing and it seems as if Cunningham is creating his own Woolf in this novel.

This is also mentioned in Brenda Silver's book Virginia Woolf: Icon: "My distrust of those who would fix Virginia Woolf into any single position either to praise her or to blame her remains my strongest motivation" (1999, p. 5). Mrs. Woolf of The Hours is one dimensional who cannot be compared to Virginia Woolf's identity who was a complex character and writer. As it is mentioned by a Woolf scholar, Tuzyline Allen: "life a Virginia Woolf knew it, was at once ecstatic and painful. From her early years in the upper middle class... Woolf straddled the extreme emotions of joy and grief, excitement and anguish" (1995, p. 20).

While Mrs. Dalloway is marked by Woolf's desire to "give the slipperiness of the soul," The Hours is marked by an oppressive consistency or sameness in Cunningham's characters (Diary, 1981, p.54). Mrs. Woolf of The Hours exposes the common reader to a characterization of Virginia Woolf that Lorraine Sim describes as "centering on her status as invalid and creative genius...disempowered by a repressive, domestic existence in suburban Richmond"(2004, p. 12). Mrs. Woolf of The Hours needs protection from everybody, specially her husband. She is anxious and mentally unstable: "I am alone, Virginia thinks... and she knows she will be utterly alone if and when the devil chooses to appear again. The devil is a headache; the devil is a voice inside a wall; the devil is a fin breaking through dark waves" (The Hours, p. 167). She is really paranoid: "Pain colonizes her, quickly replaces what was Virginia with more and more of itself, and its advance is so forceful... that she can't help imagining it as an entity which has life of its own." (The Hours, p. 70).

To depict her illness, Cunningham portrays Mrs. Woolf as suspicious: While she is watching Nelly, the Woolf's cook, "Virginia thinks, she would like to slit my throat; just so with an offhand stroke, as if killing me were another of the domestic chores that stand between her and sleep (The Hours, p. 87). Lifting the looking-glass image from Mrs. Dalloway, Cunningham shows Mrs. Woolf as suspicious even of herself. When Mrs. Woolf faces the revealing mirror, "She is aware of her reflected movements in the glass but does not permit herself to 
look. The mirror is dangerous; it sometimes shows her the dark manifestation of air that matches her body, takes her form, but stands behind, watching her, with porcine eyes and wet, hushed breathing"'( The Hours, p. 31).

Reality can also be presented through crazy people who are considered mad or insane by others. In The Hours, Richard who is suffering from AIDS and is depressed imagines the future while sitting in his dark and dirty apartment. According to Vesna Melis, Richard Brown, the mad poet of The Hours, is sitting in the "dusty disuse" of his apartment, the mad poet before his self-inflicted execution, unable to discern between the times lost and the time now, but he is painfully aware that the future is an empty promise $(2006, \mathrm{p} .11)$.

Besides, In The Hours, Cunningham uses several symbols, such as flower and bird to show his ideas and realities of our world in a strange way. These symbols help represent the significance about life and death in the novel. They may contain different and ambivalent meanings in different situations.

A variety of symbols create a personal, revealing nature in The Hours. First of all, flowers symbolize life and vitality and show intensity of emotions in The Hours. As it is clear the most notable characteristics of flowers are their sweat scene and beauty. Flowers, particularly roses, have different connotations for each of the major characters. Clarissa loves life and her surroundings. She is like flowers starting to bloom and greet the new day and life. Cunningham, in his novel, suggests that the flower is a proper symbol to describe the freshness of life and Clarissa takes great pleasure in the flowers she buys. Even in the end of Cunningham's work, the flowers Clarissa has brought home remain after Richard's death. When Clarissa Vaughan goes back to her apartment, she finds that the flowers are still there: "The flowers, of course, remain — brilliant and innocent; exploding from vases in lavish, random profusion, for Clarissa dislikes arrangements" (p. 217). The flowers for the party and for the living people still remain even after there is death.

Flowers also symbolize love in this novel; however, they can also be a symbol of death. Before Richard kills himself in the part of "Mrs. Dalloway," he tells Clarissa that death is like a gigantic flower swallowing him up: "I've felt it for some time now, closing around me like the jaws of a gigantic flower. Isn't that a peculiar analogy? It feels that way, though. It has a certain vegetable inevitability . . . It's a sort of juicy, green, thriving progress. Toward, well, you know. The green silence. Isn't it funny that, even now, it's difficult to say the word, 'death'" (p. 198)?

Besides, in the part dealing with Mrs. Woolf, helping the children bury the dead thrush, Virginia asks "shall we pick some roses too?" (p.118).and "Angelica takes one of the yellow roses they have picked and places it, carefully along the along the edge of the grass mound." (p. 119).

On the other hand, in the part of "Mrs. Brown," roses are the symbol of failure. "she returns to the kitchen and, without hesitation, picks up the cake and tips it from its milk-glass platter into the garbage can ... a yellow rose is smeared along the can's curved side" (p. 112). To Laura, the rose is a symbol of failure of being a successful housewife; therefore, symbolizing Laura's family duty that she can never run away from.

The bird (thrush) also represents the desire of freedom in The Hours. In the part dealing with Mrs. Brown, having looked at the bird outside, Laura feels happy: "Laura is briefly, deeply pleased by the shadow of the bird, the bands of brilliant white and green" (p. 75). In fact, what pleases Laura is the imagination and thought of being free from her marital life and family duty. For Virginia the bird is a symbol of death. She first notices the dead bird when Vanessa's children construct a grave for it in her garden. She takes notice of how small and insignificant the bird looks after being placed in the nest of flowers: "there now, she should be quite comfortable I think" (p. 118).

\section{Conclusion}

The above project represented some theories of postmodern narrative with an especial focus on the American play The Hours. Probing in to The Hours from a postmodern narratoligcal standpoint, and then going through the different techniques applied in the mentioned novel the researcher concluded that Michael Cunningham has used postmodern narrative to create his own special techniques of narrative within narrative to tell the story of three women, that are all related to each other in one way or another and show their concerns and pains.

In concluding this study, it will be obvious to the reader that the discussion is incomplete in several major respects. First, further research should continue to explore the novel in the light semiotic point of view.it can be discussed how Cunningham has put together the codes and historical references to construct a chain of codes leading readers in to the signifying systems the writers are inclined to impose on the texts. On the other hand, through conducting a social analysis, further research can be devoted to analyzing and interpreting the dominant discursive fields of the novel and the way Cunningham is influenced by them. Besides, since literary works can 
International Journal of Applied Linguistics \& English Literature

ISSN 2200-3592 (Print), ISSN 2200-3452 (Online)

Vol. 1 No. 4; September 2012

be thought of as mirrors reflecting the writer's society, The Hours can also be analyzed from a comparative perspective on social and cultural conditions of American society.

\section{References}

Allen, T. (1995). Womanist and Feminist Aesthetics: A Comparative Review. Athens: Ohio UP.

Bakhtin, M. (1981).The Dialogic Imagination: Four Essays. Austin: University of Texas Press.

Bal, M. (1985). Narratology: An Introduction to the Theory of Narrative. Canada: University of Toronto Press.

Barthes, R. (1977). Images-Music-Text. Trans. Stephen Heath. New York: Hill \& Wang.

Bennett, G., \& Mclean, I. (1996). The Art of Gordon Bennett. Sydney: Craftsman House.

Bergson, H. (1949). An Introduction to Metaphysics. Trans.T.E.Hulme. NewYork: The Liberal Arts Press Inc.

Brunt, A. (2004). "The Postmodern Crisis of Narrative: Byatt, Carey, and Swift". USA: Brown University.

Crew, B. (1999). Postmodern Narrative: In Search of an Alternative. Spain: University of Seville.

Cunningham, M. (1999). The Hours. London: Fourth Estate.

Derrida, Jacques. (1966). "Structure, Sign and Play in the Discourse of the Human Sciences". Trans. Alan Bass.

London: Routledge.

Genette, G. (1988). Narrative Discourse Revisited. Trans. Jane E. Lewin. Ithaca: Cornell UP.

Harrison,Sue. (1999). "Cunningham Finds God in the Details." Retrieved on September, 21, 2002.

Holquist, M., \& Walter, R.Reed. (1988). " Six These on the Novel and some Metaphors" New Literary History.

Hucheon, L. (1989). "Histographic Metafiction: Parody and Intertextuality of History."intertextuality and

Contemporary American Fiction. Ed. Patrick O Donnell and Robert Con Davis. Baltimore: The John Hopkin

University Press.

Hucheon, L. (1988). A Poetic of Postmodernism. London: Routledge.

Humphrey, R. ( 1965 ). Stream of Consciousness in the Modern Novel. Berkeley: University of California Press.

James, W. (1890). The Principles of Psychology.. New York: Dover Publications, Inc.

Jean-Francois, L. (1984). The Postmodern Condition: A Report on Knowledge. Trans. Geoff Bennington \& Brian Massumi. Minneapolis: University of Minnesota Press.

Jerome, B. (2002). Making Stories: Law, Literature, Life. Chapter 3.Cambridge: Harvard University Press.

Kristeva, J. (1984). Revolution in Poetic Language. Trans.Margaret Waller. New York: Columbia UP.

Kristeva, J. (1980). "Word, Dialogue, and Novel." Desire in Language: A Semiotic Approach to Literature and Art. Ed. LeonS. Roudiez. Trans. ThomasGora,Alice Jardine \& Leon S. Roudiez. New York: Columbia UP.

Kumar, Shiv K. ( 1963 ) . Bergson and the Stream of Consciousness Novel. NewYork: New York UP.

LitChat. (2000). "DanceswithWoolf." http://www.poz.com/archive/columns/litchat.htm.

Onega, S., \& Landa, J. (1996). Narratology: An Introduction. USA: Longman P, NewYork.

Moreland, J.P. (2005). Pluralism and Four Grades of Postmodern Involvement. Talbot School of Theology, Biola University: La Mirada, CA90639.

Online News Hour. "The Pulitzer for Fiction." http://www.pbs.org/newshour/bb/

entertainment/jan-june99/pulitzer_4-13.html.

Richter, H. ( 1970 ) . Virginia Woolf: The Inward Voyage. Princeton:PrincetonUP.

Ricoeur, P. ( 1985 ). Time and Narrative. Vol.Two. Trans.Kathleen McLaughlin linand DavidPellauer.

Chicago:TheUniversity of Chicago Press.

Silver, B. (1999). Virginia Woolf Icon. Chicago and London: The U of Chicago.

Sim, L. (2004). "No Ordinary Day: The Hours, Virginia Woolf and Everyday Life." Australia: Hecate Press.

Taylor, V., \& Winquist, C. (2003). Encyclopedia of Postmodernism. Routledge, London: New York.

Van der Laan, Sarah. ( - - ) . "A New Hour for Woolf." The Yale Review of Books. 


\section{iㅛ}

International Journal of Applied Linguistics \& English Literature

ISSN 2200-3592 (Print), ISSN 2200-3452 (Online)

Vol. 1 No. 4; September 2012

http://www.yale.edu/yrb/spring99/review08.htm.

Woolf, V. (1996). Mrs.Dalloway. London: Penguin Popular Classics.

Woolf, V. (1981). A Writer's Diary: Being Extracts from the Dairy of Virginia Woolf. Ed. Leonard Woolf. New York: Harcourt Brace Jovanovich Publishers.

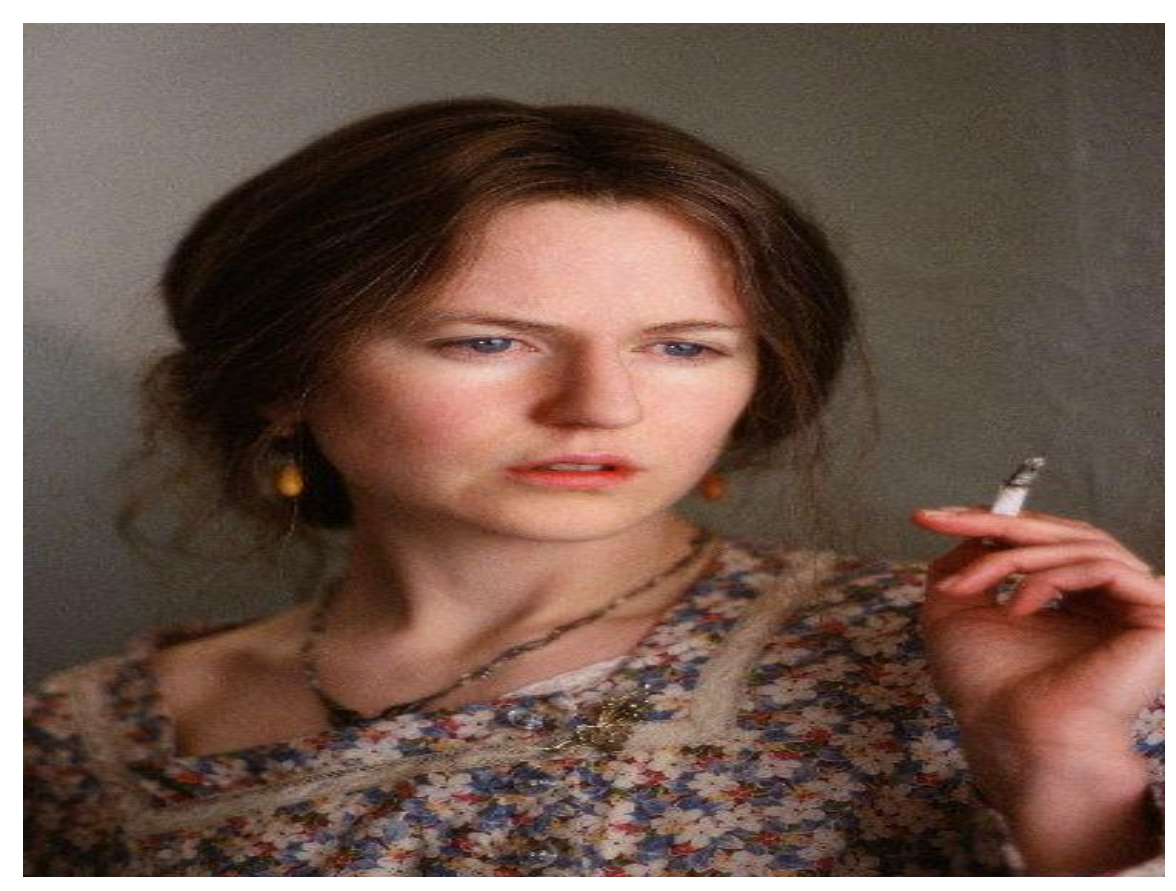

Figure A-1: Nicole Kidman asVirginia Woolf

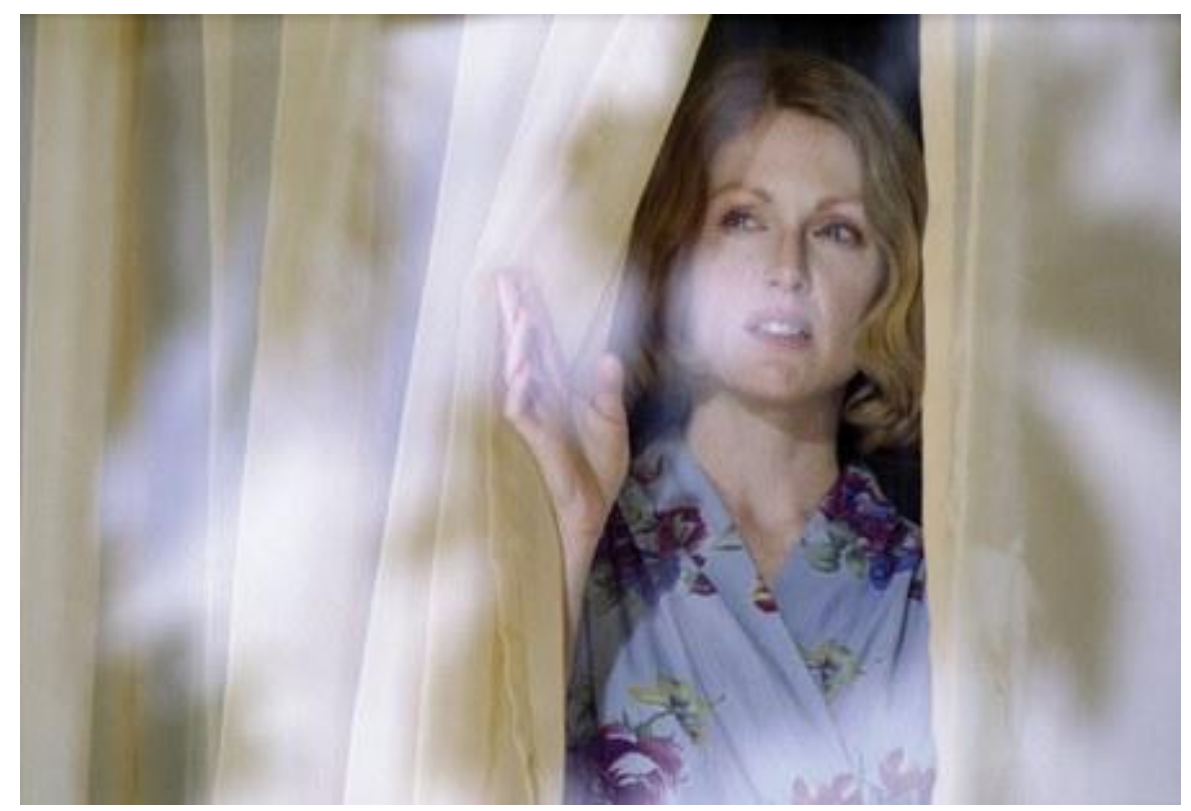

Figure A-2: Julianne Moore as Laura Brown 


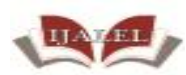

International Journal of Applied Linguistics \& English Literature ISSN 2200-3592 (Print), ISSN 2200-3452 (Online)

Vol. 1 No. 4; September 2012

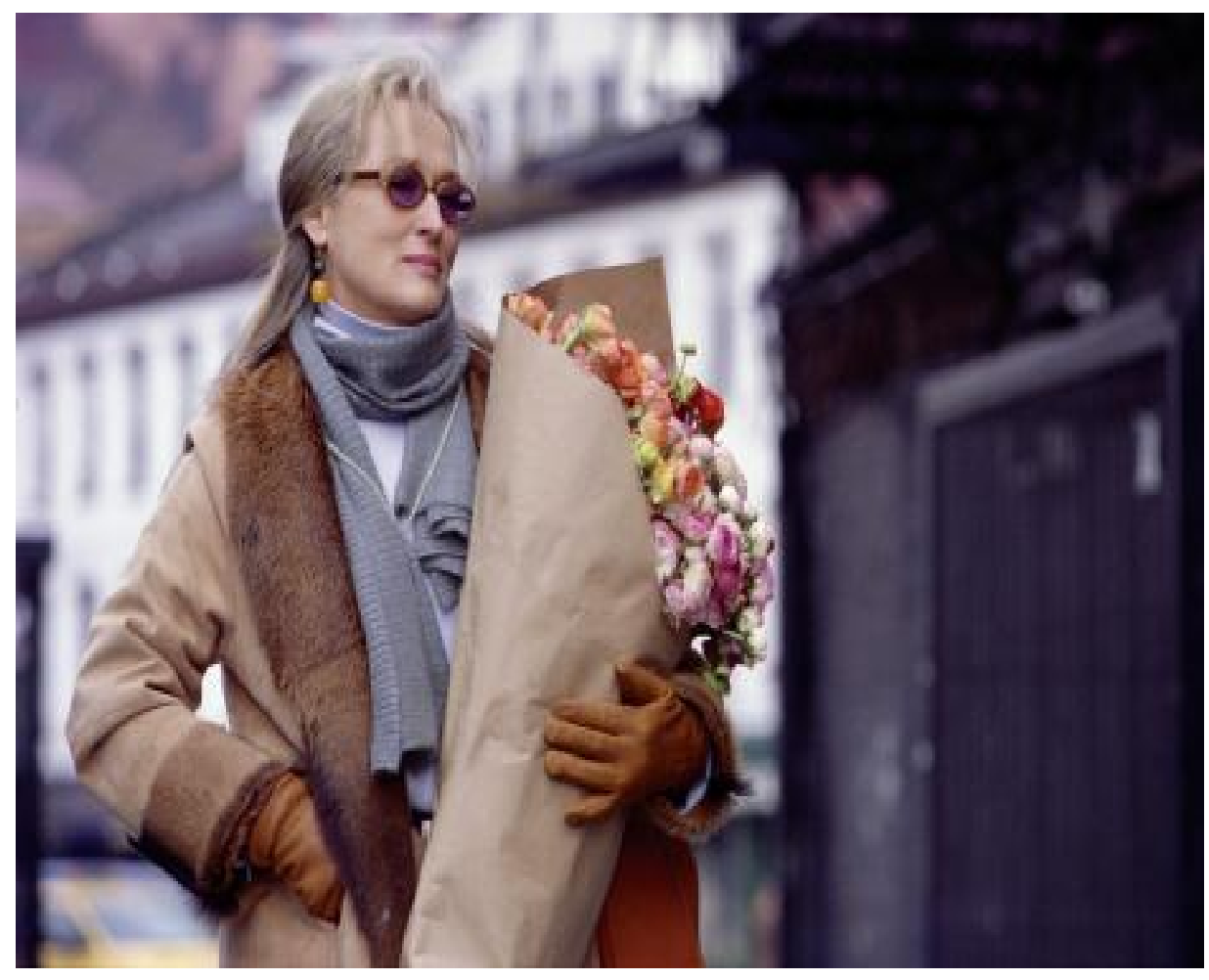

Figure A-3: Meryl Streep as Clarissa Vaughn

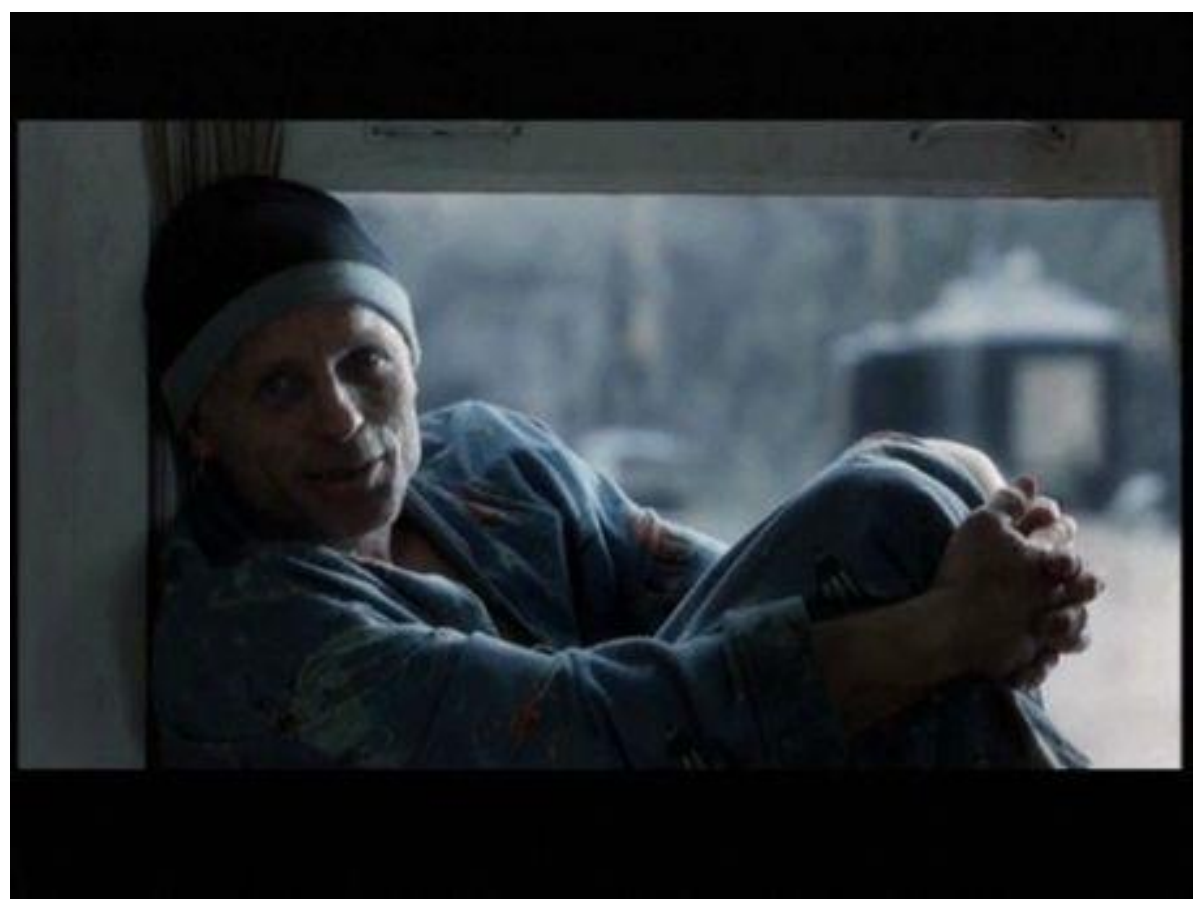

Figure A-4: Ed Harris as Richard Brown 